\title{
Revisiting Seed Transmission of the Type Strain of Tomato yellow leaf curl virus in Tomato Plants
}

\author{
Verónica Pérez-Padilla, ${ }^{1}$ Isabel M. Fortes, ${ }^{2}$ Beatriz Romero-Rodríguez, ${ }^{3}$ Manuel Arroyo-Mateos, ${ }^{3}$ Araceli G. Castillo, ${ }^{3}$ \\ Cristina Moyano, ${ }^{1}$ Leandro De León, ${ }^{1}$ and Enrique Moriones ${ }^{2, \dagger}$ \\ ${ }^{1}$ Instituto Nacional de Investigación y Tecnología Agraria y Alimentaria (INIA), Ctra. de La Coruña, km 7.5, E-28040 Madrid, Spain \\ ${ }^{2}$ Instituto de Hortofruticultura Subtropical y Mediterránea "La Mayora", Universidad de Málaga-Consejo Superior de Investigaciones \\ Científicas (IHSM-UMA-CSIC), Estación Experimental "La Mayora", E-29750 Algarrobo-Costa, Málaga, Spain \\ ${ }^{3}$ IHSM-UMA-CSIC, Área de Genética, Facultad de Ciencias, Universidad de Málaga, E-29071, Málaga, Spain \\ Accepted for publication 1 October 2019.
}

ABSTRACT

\begin{abstract}
Isolates of the Tomato yellow leaf curl virus (TYLCV) species (genus Begomovirus, family Geminiviridae) infect tomato crops worldwide, causing severe economic damage. Members of the whitefly Bemisia tabaci sibling species group are the vector of begomoviruses, including TYLCV. However, transmission of isolates of the type strain (Israel [IL]) of TYLCV (TYLCV-IL) by tomato seed has recently been reported based on infections occurring in Korea. Because of the consequences of this finding on the epidemiology and control of the disease caused by TYLCV and on the seed market, it was considered essential to revisit and expand those results to other tomato-growing areas. TYLCV DNA content was detected in tomato and Nicotiana benthamiana seed collected from plants naturally or experimentally infected with TYLCV-IL, supporting its seedborne nature. The TYLCVIL replication detected in tomato and $N$. benthamiana flower reproductive organs demonstrated close association of this virus with
\end{abstract}

the seed during maturation. However, the significant reduction of TYLCV DNA load after surface disinfections of tomato seed suggests that most of the virus is located externally, as contaminant of the seed coat. Transmission assays, carried out with seven tomato genotypes and more than 3,000 tomato plants, revealed no evidence of seed transmission from "surface-disinfected" or untreated seed for two Mediterranean isolates of TYLCV-IL. Similar results were also obtained for seed collected from TYLCV-IL-infected $N$. benthamiana plants. The results support the conclusion that TYLCV-IL is seedborne but is not seed transmitted in tomato or $N$. benthamiana, suggesting that transmission through seed is not a general property of TYLCV.

Keywords: begomovirus, disease control and pest management, ecology and epidemiology, seed transmission, tomato, tomato yellow leaf curl virus, virology
The tomato yellow leaf curl disease (TYLCD) is one of the most devastating viral diseases worldwide, severely limiting tomato (Solanum lycopersicum L.) production in warm and temperate regions (Moriones and Navas-Castillo 2000; Rybicki 2015). The symptoms of this disease consist of upward curling of leaflet margins, yellowing and reduction of leaflet area, decrease of plant growth, and flower abortion. As a result, the tomato plants are less vigorous and produce fewer fruit with reduced market value. This makes TYLCD one of the most serious threats to tomato production (Hanssen et al. 2010; Moriones et al. 2011; Navas-Castillo et al. 2011; Péréfarres et al. 2012; Rojas et al. 2018). TYLCD is caused by a complex of at least 10 viral species of the genus Begomovirus, family Geminiviridae (Brown et al. 2015), with isolates of the Tomato yellow leaf curl virus (TYLCV) species being the most widespread worldwide (Lefeuvre et al. 2010; Navas-Castillo et al. 2011). Several strains have been reported and recognized taxonomically for TYLCV by the Geminiviridae Study Group of the International Committee on Taxonomy of Viruses (Brown et al. 2015), with the type strain (or Israel strain, TYLCV-IL) (Fauquet et al. 2008) being the most prevalent (Lefeuvre et al. 2010).

†Corresponding author: E. Moriones; moriones@eelm.csic.es

Funding: E. Moriones was supported by grant AGL2016-75819-C2-2 and A. G. Castillo by grant AGL2016-75819-C2-1 from the Agencia Estatal de Investigación, Ministerio de Economía, Industria y Competitividad, Spain, with assistance from the European Regional Development Fund and the European Social Fund.

V. Pérez-Padilla and I. M. Fortes contributed equally to this work.

The author(s) declare no conflict of interest.

(C) 2020 The American Phytopathological Society
Begomovirus species such as TYLCV have a monopartite and circular single-stranded DNA genome of approximately $2.8 \mathrm{~kb}$ in size encapsidated in a twinned icosahedral or "geminate" particle (Cohen and Antignus 1994). This genome encodes six open reading frames (ORFs) that are organized bidirectionally in both virus-sense or virus-complementary sense DNA strands and diverge from a noncoding intergenic region (IR) (Zerbini et al. 2017). The virussense strand encodes the V2 precoat protein (V2 ORF), involved in the movement of the virus in plants, and the coat protein $(\mathrm{CP})(\mathrm{V} 1$ $\mathrm{ORF}$ ), involved in the movement within the plant and also between plants by insect transmission. The virus-complementary sense strand encodes the replication-associated protein (Rep) and the replication enhancer protein ( $\mathrm{C} 1$ and $\mathrm{C} 3 \mathrm{ORFs}$, respectively), which participate in the control of replication; the transcription activator protein (TrAP) (C2 ORF), which transactivates expression of virion-sense genes; and the protein $\mathrm{C} 4$ (C4 ORF), which is a pathogenicity determinant (Hanley-Bowdoin et al. 1999; Zerbini et al. 2017). TrAP, V2, and C4 have also been involved in the posttranscriptional gene silencing-suppression activity of TYLCV (Luna et al. 2012). Proteins V2 and Rep from isolates of Tomato leaf yellow curl Sardinia virus (TYLCSV) (a Begomovirus sp. closely related to TYLCV, also associated with TYLCD) have been shown to act as transcriptional gene-silencing suppressors (RodríguezNegrete et al. 2013; Wang et al. 2014).

Members of the whitefly Bemisia tabaci (Hemiptera: Aleyrodidae) sibling species group are the vector of begomoviruses, including TYLCV (Cohen and Antignus 1994; De Barro et al. 2011; Rosen et al. 2015). Thus, the worldwide expansion of invasive and polyphagous types of this whitefly such as the Middle East-Asia Minor 1 (MEAM1, formerly known as B biotype) and the Mediterranean (MED, formerly Q biotype) species has been considered a key 
factor in the emergence of TYLCV (Gilbertson et al. 2015). It has been generally accepted that begomoviruses are not vertically transmitted by seed to the progeny plants. Detection of begomoviruses in seed supports their seedborne nature (Just et al. 2017) but does not directly implicate seed transmission to progeny seedlings, as reported for other viruses (Johansen et al. 1994). However, several recent reports suggest the possibility of seed transmission in this group of viruses (Kim et al. 2015; Kothandaraman et al. 2016; Manivannan et al. 2019; Sangeetha et al. 2018; Suruthi et al. 2018). Interestingly, seed transmission of the TYLCV-IL detected in Korea in tomato plants was also reported, with high seed transmission rates (as much as $80 \%$ of seedlings infected), leading to the conclusion that TYLCVinfected seed can be even more relevant than whiteflies for TYLCV-IL spread and might be involved in the long-distance dissemination of this virus (Kil et al. 2016). Moreover, detection of TYLCV-IL in tomato embryo tissues of seed was reported by Just et al. (2017). Later reports also suggested seed transmission of TYLCV-IL in pepper (Capsicum annuum L.) and white soybean (Glycine max (L.) Merr.) (Kil et al. 2017, 2018). On the other hand, no evidence of seed transmission was observed for TYLCV-IL in a different tomato variety (Florida Lanai) (Rajabu et al. 2018) or in the permissive virus host Nicotiana benthamiana Domin (RosasDíaz et al. 2017).

Seed transmission of a virus might have a great impact on the seed industry, especially for seed production and trade, which may require the adoption of regulatory measures. Due to the importance of this aspect, the possible seed transmission reported for TYLCVIL was revisited in this work to expand those findings to other tomato genotypes and other growing areas where TYLCV-IL isolates with different biological behavior might exist. Therefore, studies were conducted with two Mediterranean (southern Spain) TYLCV-IL isolates and seven tomato genotypes (six Spanish tomato landraces and one tomato cultivar), including $N$. benthamiana as a control (all susceptible to TYLCV-IL) (Cañizares et al. 2015) (E. Moriones, unpublished data), in order to confirm whether seed collected from fruit of TYLCV-infected plants might be a source of infectious virus for progeny plants. The presence of TYLCV-IL in seed, the virus distribution in floral tissues of infected plants, and the possible seed-to-progeny plant transmission were investigated under controlled insect-proof conditions for tomato and $N$. benthamiana plants naturally (tomato) or experimentally (tomato and $N$. benthamiana) infected.

\section{MATERIALS AND METHODS}

Plant materials, virus isolate, and whitefly population. Six Spanish tomato landraces (Melillero, Rondeño, La Carlota, Zahara de la Sierra, Marmande, and Cherry Canadá; Instituto de Hortofruticultura Subtropical y Mediterránea "La Mayora", Universidad de Málaga-Consejo Superior de Investigaciones Científicas [IHSM-UMA-CSIC] seed bank) and one tomato cultivar (Moneymaker; IHSM-UMA-CSIC seed bank) were used in this study. Also, the experimental host $N$. benthamiana (IHSM-UMACSIC seed bank) was included in the assays. The infectious clone of the Mediterranean isolate ES-Alm-Pep-99 of TYLCV-IL (GenBank accession number AJ489258), previously described (Morilla et al. 2005), was used for experimental inoculations (see below). Virusfree B. tabaci adult individuals were obtained from a colony of the MED species that originated from field individuals initially collected from the field in Malaga, Spain (Sánchez-Campos et al. 1999). Whiteflies were reared on melon (Cucumis melo L. 'ANC42'; IHSM-UMA-CSIC seed bank) plants within wooden cages covered with insect-proof nets in an insect-proof glasshouse with temperature control $\left(22\right.$ to $27^{\circ} \mathrm{C}$ by day and 17 to $20^{\circ} \mathrm{C}$ by night) and supplemental light when needed.

Collection of seed from TYLCV-IL-infected tomato and $N$. benthamiana plants. Tomato and $N$. benthamiana seed were collected from fruit harvested from TYLCV-IL-infected plants. Field-infected tomato plants were selected from an assay of Spanish tomato landraces conducted in a plastic house in Malaga (Mediterranean coastal area of southern Spain) during summer 2017, in which a severe natural TYLCD infection occurred. For the detection and characterization of the TYLCV naturally infecting plants, the newest leaf of the growing point was collected from 4-month-old plants of five tomato landraces of the field assay: Melillero, Rondeño, La Carlota, Zahara de la Sierra, and Cherry Canadá. TYLCV-IL infection was demonstrated by hybridization, PCR, and genome sequence analyses (see below). Seed were then collected from fruit of four TYLCV-IL-infected plants of each of these tomato varieties. Additionally, seed were also collected from three plants each of Marmande and Rondeño landraces and Moneymaker tomato and three $N$. benthamiana plants, experimentally infected with the infectious clone of isolate ES-Alm-Pep-99 of TYLCV-IL. Inoculation of plants was carried out at the four-leaf growth stage by stem puncture using Agrobacterium tumefaciensmediated inoculation (Monci et al. 2005). These experimental inoculations were conducted in confined growth chamber conditions $\left(26^{\circ} \mathrm{C}\right.$ by day and $22^{\circ} \mathrm{C}$ at night, $70 \%$ relative humidity, with a 16-h photoperiod of photosynthetically active radiation at $250 \mathrm{~mol}$ $\mathrm{s}^{-1} \mathrm{~m}^{-2}$ ) and the inoculated plants were maintained until fruit harvest in an insect-proof glasshouse with temperature control (approximately 16-h day length, 22 to $27^{\circ} \mathrm{C}$ during the day and 17 to $20^{\circ} \mathrm{C}$ at night) and supplemental light when needed. The inoculated tomato and $N$. benthamiana plants developed typical TYLCV infection symptoms (Morilla et al. 2005) at 30 days postinoculation (dpi) and the presence of the virus in young, noninoculated tissues was then confirmed by tissue blot hybridization and PCR analyses (see below). Tomato seed were collected from ripe fruit following three different methods: (i) washing thoroughly with distilled water to remove the tomato fruit flesh (W treatment), (ii) washing thoroughly with distilled water followed by surface disinfection by immersion in $75 \%$ ethanol for $10 \mathrm{~min}$ and $50 \%$ bleach (approximately $1.5 \%$ sodium hypochlorite) for $20 \mathrm{~min}$ (WD treatment), and (iii) seed removed by fruit flesh fermentation for $48 \mathrm{~h}$ at room temperature and then washing with abundant distilled water (Nemati et al. 2010) followed by surface disinfection by immersion in $75 \%$ ethanol for $10 \mathrm{~min}$ and $50 \%$ bleach for $20 \mathrm{~min}$ (FD treatment). Collected seed were then dried at $25^{\circ} \mathrm{C}$ in a heater with air recirculation for $24 \mathrm{~h}$ to complete drying and stored at $4^{\circ} \mathrm{C}$ until used. As negative controls, seed were also collected from fruit of virus-free Marmande tomato plants (cultivated under confined insect-proof conditions). The seed germination was evaluated by sowing 35 tomato seeds/treatment, with similar germination efficiency observed in every case. $N$. benthamiana seed were collected from mature seed capsules of TYLCV-IL-infected or virus-free control plants (cultivated under confined insect-proof conditions).

Detection of TYLCV in plants and seed. Presence of a TYLCD-associated virus in plants was determined by hybridization of tissue blots from petiole cross-sections, as described by Monci et al. (2002). Probes specific to isolates of TYLCV or TYLCSV (Navas-Castillo et al. 1999), which detect all of the TYLCDassociated begomoviruses reported in the Mediterranean region (García-Andrés et al. 2007), were used. Viral detection was also conducted on total DNA extracted from young leaves of naturally and experimentally infected plants and from seed samples with either conventional PCR or quantitative real-time PCR (qPCR). For bulk analyses, bulk samples from 10 leaves $(0.2 \mathrm{~g}$ per individual plant) or 10 seeds were used for DNA extraction and subsequent PCR or qPCR analysis. The seed samples from tomato and $N$. benthamiana, were ground ( $1 \mathrm{~min}$ at $30 \mathrm{rpm}$ ) with a steel bead using the homogenizer Retsch Mixer Mill MM-400. Individual or bulk samples of leaves were homogenized in a Stomacher 80 Biomaster/ Filter Bags (Seward Ltd.) in $5 \mathrm{ml}$ of phosphate-buffered saline ( $\mathrm{pH}$ 7.4) supplemented with Tween-20 (0.02\%); homogenized samples 
were kept at $4^{\circ} \mathrm{C}$ during processing until DNA extraction from a volume of $100 \mu \mathrm{l} / \mathrm{sample}$. Total DNA was extracted from leaves and seed using the TRIsure reagent extraction procedure (Bioline) following the instructions of the manufacturer. Total DNA was also extracted from individual leaf samples by a modified cetyltrimethylammonium bromide (CTAB) method (Permingeat et al. 1998). For conventional PCR, combinations of specific primers for TYLCSV or TYLCV were used (García-Andrés et al. 2007) (Table 1). The primer combination MA272/MA273 is specific to TYLCSV and amplifies a fragment of $679 \mathrm{bp}$ encompassing part of the Rep, C1 ORF (275 nucleotides [nt], including $124 \mathrm{nt}$ overlapping with the $5^{\prime}$ end of the C4 ORF), the entire IR, and the $5^{\prime}$ proximal part of de V2 ORF (100 nt); the primer combination MA272/MA274 is specific to TYLCV and amplifies a fragment of 683 bp encompassing part of the Rep, C1 ORF (269 nt, including 121 nt overlapping with the $5^{\prime}$ end of the $\mathrm{C} 4 \mathrm{ORF}$ ), the entire IR, and the 5'-proximal part of de V2 ORF (251 nt). For qPCR, the primers used were TYLCV-INIA1-F/TYLCV-INIA2-R (Table 1) that specifically amplify a fragment of $111 \mathrm{bp}$ on Rep (C1 ORF) of TYLCV. Conventional PCRs were conducted in an iCycler Thermal Cycler (Bio-Rad). Cycling parameters were $10 \mathrm{~min}$ at $95^{\circ} \mathrm{C} ; 35$ cycles of $15 \mathrm{~s}$ at $95^{\circ} \mathrm{C}, 30 \mathrm{~s}$ at $58^{\circ} \mathrm{C}$, and $30 \mathrm{~s}$ at $72^{\circ} \mathrm{C}$, and a final step of $10 \mathrm{~min}$ at $72^{\circ} \mathrm{C}$. The reaction mix (final volume of $25 \mu \mathrm{l}$ ) consisted of $3 \mu \mathrm{l}$ of DNA template ( $65 \mathrm{ng}$ of extracted total DNA), $0.2 \mu \mathrm{M}$ primers, $1.5 \mathrm{mM} \mathrm{MgSO}_{4}, 0.2 \mathrm{mM}$ dNTPs, $1 \times$ buffer, and $1 \mathrm{U}$ of IMMOLASE Red DNA polymerase (BioLine Reagents Ltd.). PCR products were visualized on $1.5 \%$ agarose gels with ethidium bromide. The PCR analysis was repeated twice. For direct sequencing of PCR-amplified fragments, PCR products were fractionated by electrophoresis in agarose gels and, after elution, both strands were sequenced (Macrogen Inc.) by priming the sequencing reactions with the same oligonucleotides used for the amplification. Viral load was determined by qPCR on total DNA extracts. Amplification of endogenous genes (cytochrome oxidase gene for tomato and 25S ribosomal RNA gene for $N$. benthamiana) (Table 1) was used as a control to normalize DNA load for sample comparison. Quantification data were based on three technical replicates per sample. Assays of qPCR were carried out using a 7500 Fast Real-Time PCR System (Applied Biosystems) under the following conditions: $10 \mathrm{~min}$ at $95^{\circ} \mathrm{C}$ for initial denaturation; 40 cycles of $15 \mathrm{~s}$ at $95^{\circ} \mathrm{C}$ and $30 \mathrm{~s}$ at $65^{\circ} \mathrm{C}$; then $15 \mathrm{~s}$ at $95^{\circ} \mathrm{C}, 1 \mathrm{~min}$ at $60^{\circ} \mathrm{C}$, and $15 \mathrm{~s}$ at $95^{\circ} \mathrm{C}$ for the melting curve analysis. The reaction mix $(15 \mu \mathrm{l})$ consisted of $7.5 \mu \mathrm{l}$ of $2 \times$ iTaq Universal SYBR Green Supermix (Bio-Rad), $10 \mathrm{mM}$ forward and reverse primers, and $65 \mathrm{ng}$ of extracted total DNA as template. Negative controls were obtained from virus-free Marmande or Moneymaker tomato and from virus-free $N$. benthamiana plants. Positive controls were obtained from Marmande and Moneymaker tomato and $N$. benthamiana plants experimentally infected with TYLCV-IL. In the latter case, positive PCR controls consisted of total DNA extracted from a TYLCV-IL-infected leaf. For analyses of seed, positive PCR controls consisted of DNA extracted from a TYLCVIL-infected leaf diluted (1:10 dilution) in total DNA extract from seed collected from fruit or seed capsules of virus-free tomato Marmande or N. benthamiana plants, respectively.

Production of $N$. benthamiana 2IRGFP and $S$. lycopersicum 'Moneymaker' 2IRDsRed transgenic lines. The plasmid p2IR-GFP and the $N$. benthamiana 2IRGFP line were described elsewhere (Maio et al. 2019). The plasmid p2IRDsRed was obtained by replacing the green fluorescent protein (GFP) from the plasmid p2IRGFP (Maio et al. 2019) by DsRed. For this, the plasmid p2IR-GFP was linearized with SacI and bluntended to facilitate subcloning. Then, the GFP coding region was

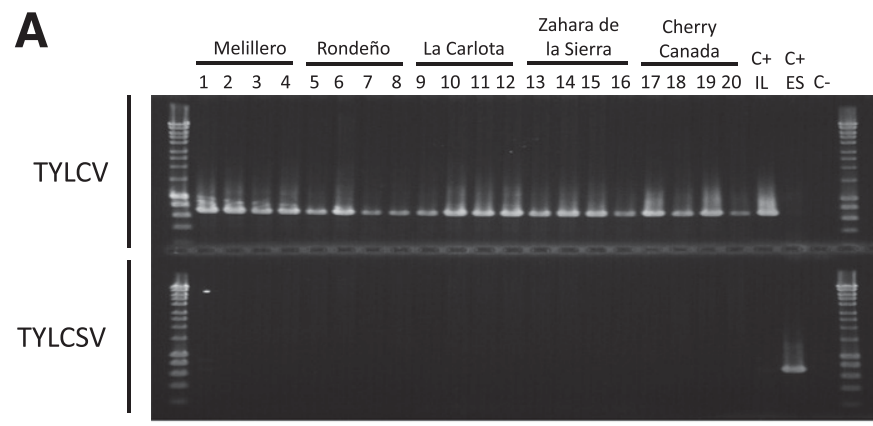

B

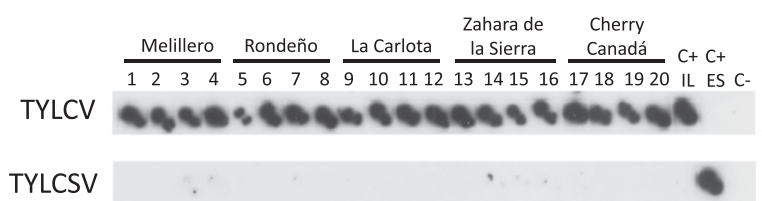

Fig. 1. Detection of tomato yellow leaf curl virus (TYLCV) in naturally infected tomato plants of five Spanish tomato landraces (Melillero, Rondeño, La Carlota, Zahara de la Sierra, and Cherry Canada). A, Detection of TYLCV and tomato yellow leaf curl Sardinia virus (TYLCSV) by PCR in DNA extracts of young tissues of tomato plants and $\mathbf{B}$, hybridization analysis of tissue blots from petiole cross-sections of young leaves using probes specific to TYLCV or TYLCSV. Four tomato yellow leaf curl disease symptomatic plants were analyzed per tomato landrace; positive controls from tomato plants infected with isolates of the Israel strain of TYLCV (C+ IL) or of the Spain strain of TYLCSV (C+ ES), and negative controls from virus-free tomato plants (C-) were included.

TABLE 1. Primers used in conventional PCR or quantitative real-time PCR (qPCR) to detect tomato yellow leaf curl disease-associated viruses, and the endogenous nuclear-encoded large ribosomal subunit RNA (25S ribosomal RNA [rDNA] gene) or the cytochrome oxidase (COX) plant genes in seed and leaves of tomato and Nicotiana benthamiana plants

\begin{tabular}{|c|c|c|c|c|}
\hline Primer & Nucleotide sequence $\left(5^{\prime} \rightarrow 3^{\prime}\right)$ & $\begin{array}{l}\text { Nucleotide } \\
\text { position }^{\mathrm{a}}\end{array}$ & $\begin{array}{c}\text { GenBank accession } \\
\text { number }^{\mathrm{b}}\end{array}$ & Reference \\
\hline MA-272c & CTGAATGTTYGGATGGAAATGTGC & $2,342-2,365$ & X61153 & García-Andrés et al. 2007 \\
\hline MA-273c & GGTTCGTAGGTTTCTTCAACTAG & $247-225$ & X61153 & García-Andrés et al. 2007 \\
\hline MA-274c & GCTCGTAAGTTTCCTCAACGGAC & 413-391 & $\mathrm{X} 15656$ & García-Andrés et al. 2007 \\
\hline TYLCV-INIA1-F ${ }^{\mathrm{d}}$ & СССССТTTAATTTGAATGGGCTT & $1,907-1,929$ & $\mathrm{X} 15656$ & This work \\
\hline TYLCV-INIA2-R ${ }^{\mathrm{d}}$ & CATTGATGACGTAGACCCGCA & $2,017-1,997$ & X15656 & This work \\
\hline $\mathrm{COX}-\mathrm{F}^{\mathrm{e}}$ & CGTCGCATTCCAGATTATCCA & $1,488-1,508$ & X83206 & Weller et al. 2000 \\
\hline COX-R ${ }^{\mathrm{e}}$ & CAACTACGGATATATAAGAGCCAAAACTG & $1,566-1,538$ & X83206 & Weller et al. 2000 \\
\hline 25S rDNA UNIV $(+)^{\mathrm{e}}$ & ATAACCGCATCAGGTCTCCA & $1,837-1,856$ & $\mathrm{X} 13557$ & Mason et al. 2008 \\
\hline 25S rDNA UNIV (-) $)^{\mathrm{e}}$ & CCGAAGTTACGGATCCATTT & $1,926-1,907$ & $\mathrm{X} 13557$ & Mason et al. 2008 \\
\hline
\end{tabular}

a Nucleotide numbers according to sequence deposited in GenBank with accession number indicated for primer design.

b Primers designed on the sequence of the GenBank accession number indicated.

c Primers used in conventional PCR.

$\mathrm{d}$ Primers used in qPCR.

e Primers used in qPCR to amplify plant endogenous genes for data normalization. 
excised from the plasmid by digestion with $X b a \mathrm{I}$, leaving $\mathrm{Xba \textrm {I }}$ blunt ends in the plasmid backbone (p2IR-XB). Next, pCXDsRed (kindly provided by Dr. O. Voinnet) was linearized with BamHI, blunt-ended, and digested with XbaI, and a 678-bp fragment containing the DsRed ORF with blunt ends was obtained and subcloned in the p2IR-XB vector to generate pBINX1-DsRed. $S$. lycopersicum 'Moneymaker' plants were transformed with pBINX1-DsRed using A. tumefaciens and selected for DsRed expression after TYLCV infection (tomato Moneymaker 2IRDsRed transgenic line). T3 homozygous plants were generated and used in this work.

Monitoring TYLCV-IL replication in $N$. benthamiana 2IRGFP and tomato 2IRDsRed transgenic lines. $N$. benthamiana flowers from TYLCV-IL-experimentally infected 2IRGFP and mock (noninfected, negative control) plants were harvested at $18 \mathrm{dpi}$, immersed in agarose $2 \%$, and dissected with a scalpel. Tomato flowers from TYLCV-IL-experimentally infected 2IRDsRed and mock (noninfected) plants were harvested at $11 \mathrm{dpi}$ and dissected with a scalpel. The flower reproductive organs were photographed with an epifluorescence microscope ZEISS Stereo Discovery V12.

Cloning, sequencing, and sequence analysis of the TYLCV-IL naturally infecting tomato. The sample named "Spain-Malaga-TY16-Tomato-2017" consisted of young apical leaves collected from one of the four TYLCD-symptomatic plant of the tomato landrace Melillero demonstrated to be naturally infected with TYLCV and used to collect tomato seed (see above). Total DNA was purified from tomato leaves using a CTAB-based purification method (Permingeat et al. 1998) and circular DNA enriched by rolling circle amplification (RCA) (Haible et al. 2006) using the $\varphi 29$ DNA polymerase (TempliPhi kit; GE Healthcare), according to the manufacturer's instructions. RCA-amplified products were digested with the single-cutter (Haible et al. 2006) restriction enzyme $\mathrm{SacI}$ and approximately 2.8 -kpb fragments were purified from agarose gel and ligated into the SacI cloning site of pBluescript SK+ (Stratagene). A virus-specific clone was selected to derive the full-length viral genomic sequence of the cloned isolate (named Spain-Malaga-TY16-Tomato-2017, acronym ESMlg-TY16-Tom-2017) by using a primer-walking strategy (Macrogen Inc.).

The analysis of the genetic relationships with full-length sequences of TYLCD-related isolates available in databases was done by using the Multiple Sequence Comparison by LogExpectation (MUSCLE) computer software (Edgar 2004). Pairwise nucleotide identity comparisons were calculated using the Sequence Demarcation Tool program (version 1.2) (Muhire et al. 2014) with the MUSCLE (Edgar 2004) option for sequence alignment.

Evaluation of seed-to-progeny plants TYLCV-IL transmission. To investigate the possible transmission of TYLCV-IL from the seed to the derived progeny seedlings, tests were carried out under confined, insect-proof growth-chamber conditions (see above) to avoid the presence of the vector B. tabaci. Assays for tomato were conducted in two geographically distant locations (INIA, Madrid, and IHSM-CSIC, Malaga). Assays for $N$. benthamiana were conducted at IHSM-CSIC. In each experiment, 10 tomato Marmande or Moneymaker plants (for tomato assays) or $10 \mathrm{~N}$. benthamiana plants (for $\mathrm{N}$. benthamiana assays) were experimentally inoculated with TYLCV-IL or mock inoculated (at the three-leaf growth stage) for virus-infected positive and virus-free negative controls, respectively. Progeny plants were visually inspected for the presence of TYLCD symptoms at 40 and 60 days after seed sowing (10- and 20-leaf growth stages, respectively). One apical leaf from each plant was collected at 60 days after seed sowing to determine the presence of TYLCV by tissue-blot hybridization. Also, bulk samples from 10 plants (one apical leaf per plant) were used for conventional PCR or qPCR TYLCV detection. The positive control consisted of a bulk of one apical leaf from each of nine virus-free mock-inoculated plants and one TYLCV-IL-infected control plant in order to dilute the initial excess of template and avoid PCR saturation. Negative controls consisted of bulk samples from 10 virus-free mockinoculated plants.

Transmission with B. tabaci. Transmission experiments were carried out using adults of the B. tabaci MED species that were given a 24-h acquisition access period (AAP) on source plants. Control viruliferous whiteflies were obtained by feeding (24-h AAP) B. tabaci virus-free adults on TYLCV-IL-infected young leaves of Moneymaker plants experimentally infected 3 weeks before with TYLCV-IL ES-Alm-Pep-99. After the AAP, whiteflies were transferred to each of 10 virus-free Moneymaker test plants at

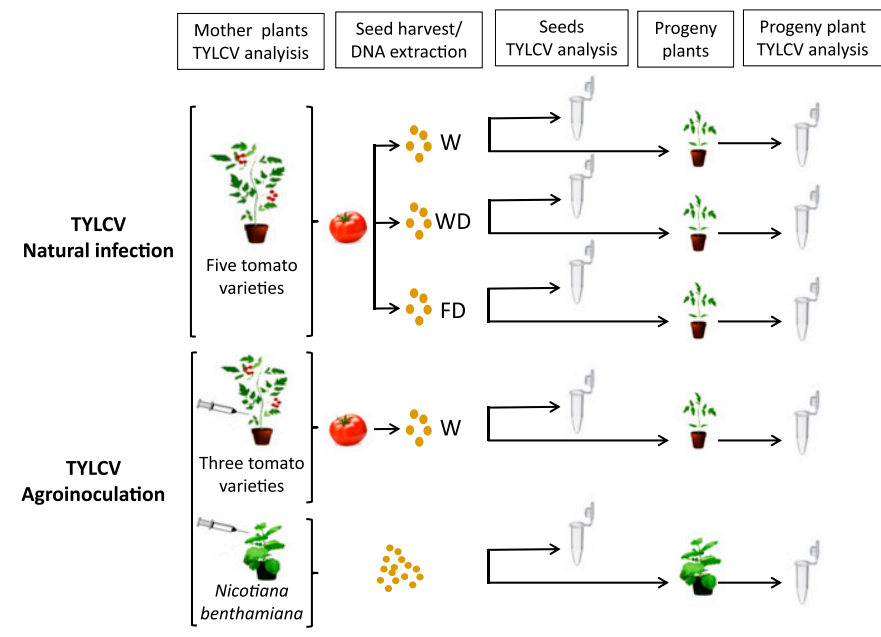

Fig. 2. Schematic diagram of the process followed to evaluate the seed transmission of isolates of the Israel strain of tomato yellow leaf curl virus (TYLCV-IL) in tomato and Nicotiana benthamiana plants. Plants naturally infected with isolates of TYLCV-IL or experimentally infected with an infectious clone of the TYLCV-IL isolate ES-Alm-Pep-99 by Agrobacterium tumefaciens-mediated inoculation (agroinoculation) were used as mother plants for seed collection. Seed were collected from tomato fruit by washing with distilled water $(\mathrm{W})$ or $48 \mathrm{~h}$ of fermentation followed by distilled water washing (F). Disinfection with $75 \%$ ethanol for 10 min and $50 \%$ bleach (approximately $1.5 \%$ sodium hypochlorite) for $20 \mathrm{~min}$ was done to some seed lots (WD and FD). For $N$. benthamiana, seed were directly collected from mature seed capsules.

TABLE 2. Comparison of the genome sequence of the tomato yellow leaf curl virus Israel strain (TYLCV-IL) isolate ES-Mlg-TY16-Tom-2017 (GenBank MG715488) characterized in this study from a naturally infected tomato plant with that of TYLCV-IL isolate ES-Alm-Pep-99 (GenBank AJ489258)

\begin{tabular}{lcccccccc}
\hline & \multicolumn{9}{c}{ Percentage of nucleotide sequence identity (amino acid similarity) } \\
\cline { 2 - 7 } TYLCV-IL isolate & Complete & IR & V2 & V1 (CP) & C1 (Rep) & C2 (TrAP) & C3 (Ren) & C4 \\
\cline { 3 - 8 } ES-Alm-Pep-99 & 99.00 & 97.76 & $99.72(99.14)$ & $99.36(99.22)$ & $98.79(98.04)$ & $99.26(100)$ & $100(100)$ & $98.64(98.97)$ \\
\hline
\end{tabular}

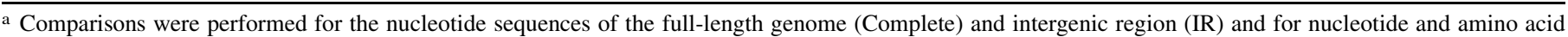
sequences of the open reading frames (proteins) V2 (precoat protein), V1 (coat protein [CP]), C1 (replication-associated protein [Rep]), C2 (transcription activator protein [TrAP]), C3 (replication enhancer protein [Ren]), and C4. 
the three-leaf growth stage ( 60 whiteflies per test plant using clip-on cages) for a 48-h inoculation access period (IAP). Transmission was conducted under insect-proof conditions in a growth chamber (see above) and within a wooden cage covered with a whitefly-proof net. After the IAP, plants were treated with insecticide and maintained until analyzed for TYLCV presence in young tissues and evaluation of appearance of TYLCD symptoms.

Statistical analysis. Relative DNA amounts of TYLCV detected by qPCR in treated (surface disinfected) and nontreated tomato seed were calculated and compared statistically. The analysis was conducted based on $n=45$ samples, with 10 pooled seeds per sample and 3 samples per tomato landrace naturally infected with TYLCV-IL and treatment. One-way analysis of variance with posthoc Tukey-b test $(P<0.05)$ was used to establish significant differences among means.

\section{RESULTS AND DISCUSSION}

Presence of TYLCV-IL in field-infected tomato plants. Twenty TYLCD-symptomatic tomato plants from five different susceptible Spanish tomato landraces grown in a tomato field assay conducted in Malaga (southern Spain) under natural infection conditions were tested for infection with TYLCD-associated begomoviruses. All plants tested positive for TYLCV infection by PCR amplification (Fig. 1A) and hybridization (Fig. 1B), whereas negative results were obtained for TYLCSV. Similarly, positive hybridization and PCR results were obtained for the three plants each of tomato landraces Marmande and Rondeño, Moneymaker, and $N$. benthamiana experimentally inoculated with the TYLCV-IL isolate ES-Alm-Pep-99 (data not shown).

Sequence analysis of the partial genome fragments amplified by PCR from all of the naturally infected tomato plants tested revealed identical TYLCV-related sequences and, therefore, a representative sample obtained from one of the plants of the tomato Melillero variety (Spain-Malaga-TY16-Tomato-2017) was used to characterize the begomovirus present. The full-length genome sequence obtained for the isolate present in this sample (GenBank accession number MG715488) exhibited its highest nucleotide sequence identity $(99.0 \%)$ with the genome sequence of the isolate ES-AlmPep-99 of TYLCV-IL previously reported in Spain (GenBank AJ489258) and used to experimentally inoculate plants in this study. Comparison of the two genome sequences revealed a high degree of nucleotide identity and amino-acid similarity in all ORFs and highest diversity in the IR, the most variable region in begomoviruses (Table 2) (Sánchez-Campos et al. 2002). According to the current rules for species and strain demarcation in begomoviruses (Brown et al. 2015), the newly characterized TYLCV field isolate is an isolate of TYLCV-IL. This isolate was considered a representative of the TYLCV-IL isolates detected in the naturally infected tomato plants analyzed. Therefore, plants from which seed were collected were infected with TYLCV-IL, the most widely spread worldwide begomovirus (Lefeuvre et al. 2010).

Seedborne nature of TYLCV-IL. Seed were collected from fruit of tomato plants naturally (five tomato landraces) or

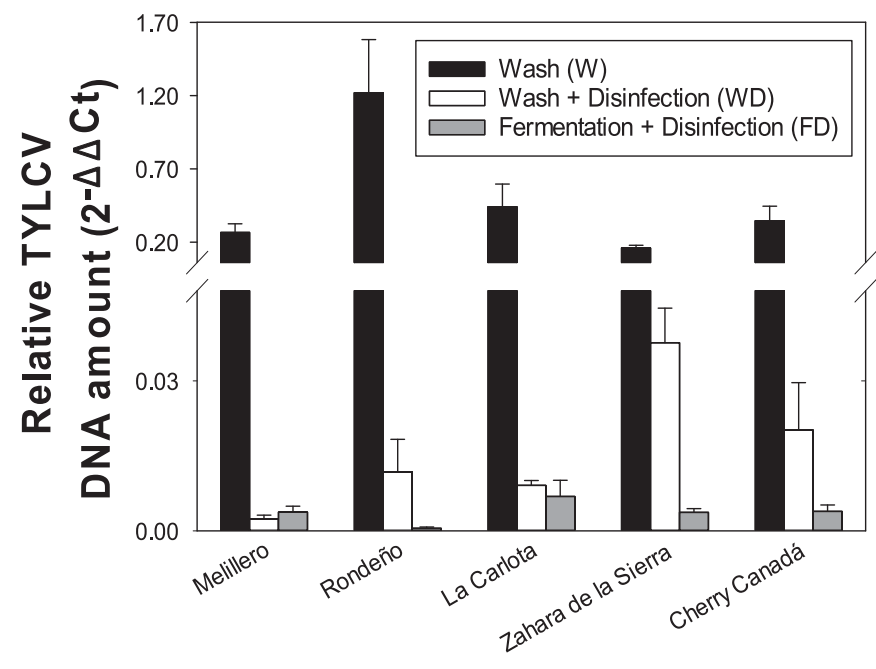

Tomato landrace

Fig. 3. Relative tomato yellow leaf curl virus (TYLCV) DNA amount in seed collected from tomato fruit of plants of five Spanish tomato landraces naturally infected with isolates of the Israel strain of TYLCV. Seed were collected from tomato fruit by washing with distilled water (W) or $48 \mathrm{~h}$ of fermentation followed by distilled water washing (F). Disinfection with $75 \%$ ethanol for 10 min and 50\% bleach (approximately 1.5\% sodium hypochlorite) for $20 \mathrm{~min}$ was also done to some seed lots (WD and FD). Viral load was determined by the $2^{-\Delta \Delta \mathrm{Ct}}$ method after quantitative real-time PCR detection of TYLCV with the endogenous cytochrome oxidase plant gene used as reference for normalization and relativized to the average value of the $\mathrm{W}$ treatment of the Rondeño tomato variety that exhibited maximum virus accumulation. Means and standard errors of the $2^{-\Delta \Delta \mathrm{Ct}}$ are displayed.

TABLE 3. Detection of tomato yellow leaf curl virus (TYLCV) by quantitative real-time PCR (qPCR) in seed collected from tomato fruit or Nicotiana benthamiana seed capsules of plants naturally or experimentally infected with isolates of the type (Israel) strain of TYLCV (TYLCV-IL) ${ }^{\mathrm{a}}$

\begin{tabular}{|c|c|c|c|c|c|c|}
\hline \multirow[b]{2}{*}{ Landrace or cultivar } & \multicolumn{2}{|c|}{$\mathrm{W}(n)$} & \multicolumn{2}{|c|}{$\mathrm{WD}(n)$} & \multicolumn{2}{|c|}{$\mathrm{FD}(n)$} \\
\hline & Seeds ${ }^{b}$ & Pos/total & Seeds ${ }^{b}$ & Pos/total ${ }^{c}$ & Seeds ${ }^{b}$ & Pos/total ${ }^{\mathrm{c}}$ \\
\hline \multicolumn{7}{|l|}{ Natural infection } \\
\hline Tomato Melillero & 30 & $3 / 3$ & 30 & $3 / 3$ & 30 & $3 / 3$ \\
\hline Tomato La Carlota & 30 & $3 / 3$ & 30 & $3 / 3$ & 30 & $3 / 3$ \\
\hline Tomato Zahara de la Sierra & 30 & $3 / 3$ & 30 & $3 / 3$ & 30 & $3 / 3$ \\
\hline Tomato Cherry Canadá & 30 & $3 / 3$ & 30 & $3 / 3$ & 30 & $3 / 3$ \\
\hline Tomato Rondeño & 30 & $3 / 3$ & $\ldots$ & $\ldots$ & $\ldots$ & $\ldots$ \\
\hline Tomato Moneymaker & 30 & $3 / 3$ & $\ldots$ & $\ldots$ & $\ldots$ & $\ldots$ \\
\hline Nicotiana benthamiana & 300 & $30 / 30$ & & & & \\
\hline \multicolumn{7}{|l|}{ Virus-free control } \\
\hline Tomato Marmande & 30 & $0 / 3$ & $\ldots$ & $\ldots$ & $\ldots$ & $\ldots$ \\
\hline Nicotiana benthamiana & 50 & $0 / 5$ & $\ldots$ & $\ldots$ & $\ldots$ & $\ldots$ \\
\hline
\end{tabular}


experimentally (two tomato landraces, one tomato cultivar, and N. benthamiana) infected with TYLCV-IL (Fig. 2). Extracted DNA from seed collected from tomato plants (landraces Melillero, Rondeño, La Carlota, Zahara de la Sierra, and Cherry Canadá) naturally infected with TYLCV-IL provided a positive result for TYLCV detection by qPCR analysis (cycle threshold values $<20$ for positive control and seed sample extracts and $>35$ for negative control) regardless of the seed extraction method used (Table 3; Fig. 2). Similar positive results for TYLCV detection were also obtained for seed collected from plants of tomato landraces Marmande and Rondeño, Moneymaker, and $N$. benthamiana plants experimentally infected with the TYLCV-IL isolate ES-Alm-Pep-99 (Table 3; Fig. 2). Sequence analysis of TYLCV partial fragments amplified by PCR from seed extracts of one bulk sample of each nondisinfected (W) or surface-disinfected (WD and FD) seed resulted in sequences identical to those of the TYLCV-IL present in the infected source plants (data not shown). Detection of TYLCV-IL in tomato (Seogwang; Seminis) seed collected from fruit of plants infected with this virus was also observed by Kil et al. (2016). These results are in agreement with the observation made by Just et al. (2017) that showed the presence of TYLCV-IL in tissues associated with tomato seed. Similar detection in seed has also been reported for other geminiviruses in host species different from tomato such as sweet potato (Ipomoea batatas (L.) Lam.), black gram (Vigna mungo (L.) Hepper), or petunia (Petunia $\times$ hybrida) (Anabestani et al. 2017; Kim et al. 2015; Kothandaraman et al. 2016). Therefore, it was concluded that TYLCV-IL could be detected in seed from infected plants of six different tomato landraces (Melillero, Rondeño, La Carlota, Cherry Canada, Zahara de la Sierra, and Marmande), Moneymaker, and N. benthamiana. These results support a seedborne nature for TYLCV-IL.

Analysis by qPCR revealed the presence of a variable and relatively high TYLCV DNA load associated with the tomato seed from infected plants (data not shown). However, a drastic reduction in TYLCV DNA load was observed in every case in seed that were subjected to surface disinfection during the seed collection process (W versus WD or FD) (Fig. 3). This strongly suggests that most of the TYLCV was located externally, as contaminant of the seed coat. The efficacy of tomato seed disinfection to eliminate the contaminant viruses located in the external surface of seed was already demonstrated in other viral systems (Córdoba-Sellés et al. 2007). Nevertheless, even in surface-disinfected seed, a relatively small load of TYLCV DNA was detected (Fig. 3, WD and FD treatments) suggesting that TYLCV-IL could be present internally in seed. Internal localization of TYLCV-IL in tomato seed is compatible with previous results showing TYLCV-IL presence in embryo tissues of tomato seed (Just et al. 2017).

Presence of TYLCV-IL in flower reproductive organs. To further characterize the localization of TYLCV-IL in the flower reproductive organs of tomato and $N$. benthamiana plants, a geminivirus-based fluorescent protein signal amplification system previously used to monitor TYLCSV replication in live tissue (Lozano-Durán et al. 2011; Morilla et al. 2006) was implemented. Plants of $N$. benthamiana (2IRGFP) and tomato (2IRDsRed)
A
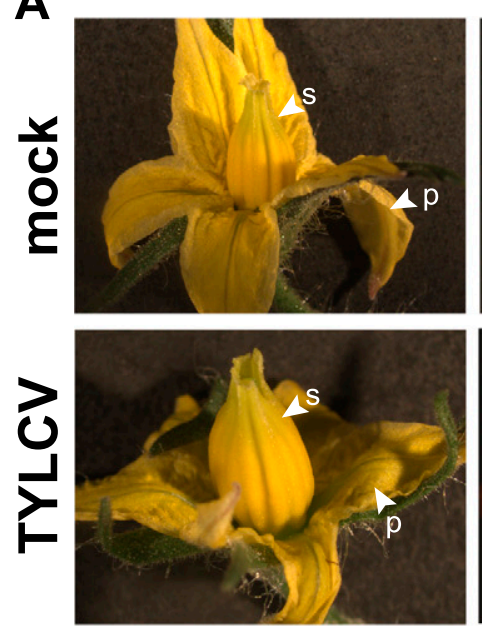

mock

C

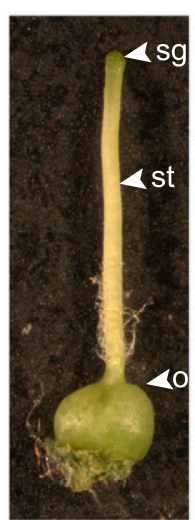

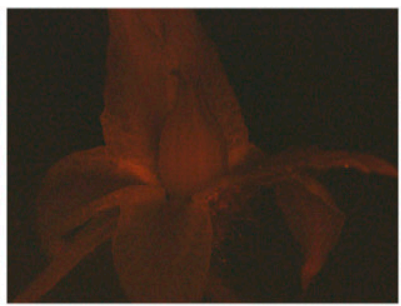

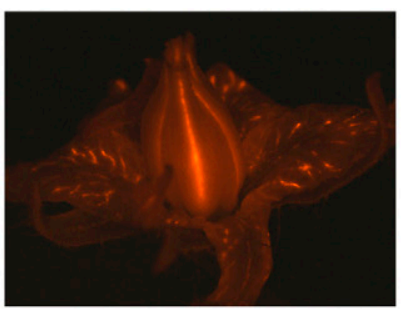

\section{TYLCV}

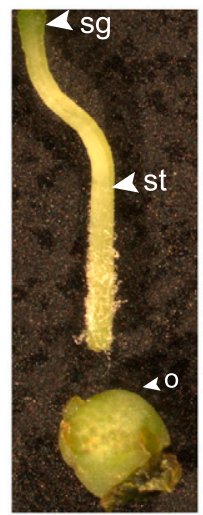

B
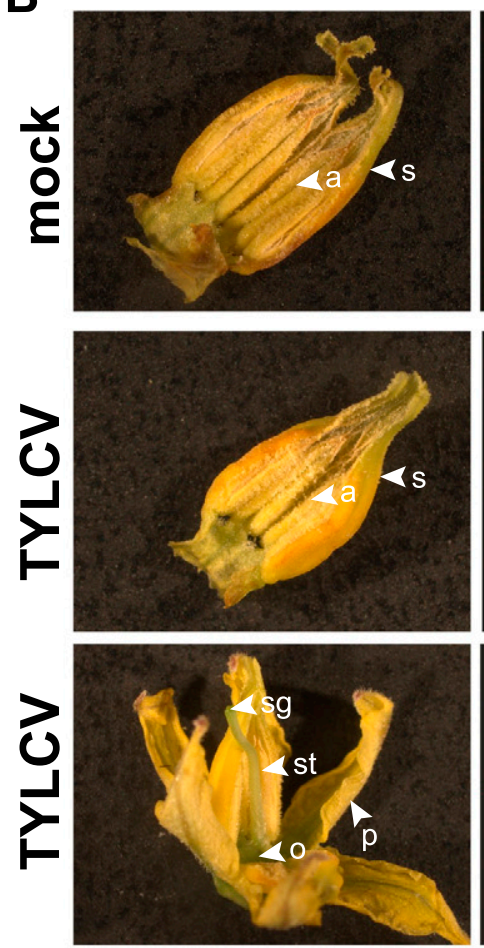
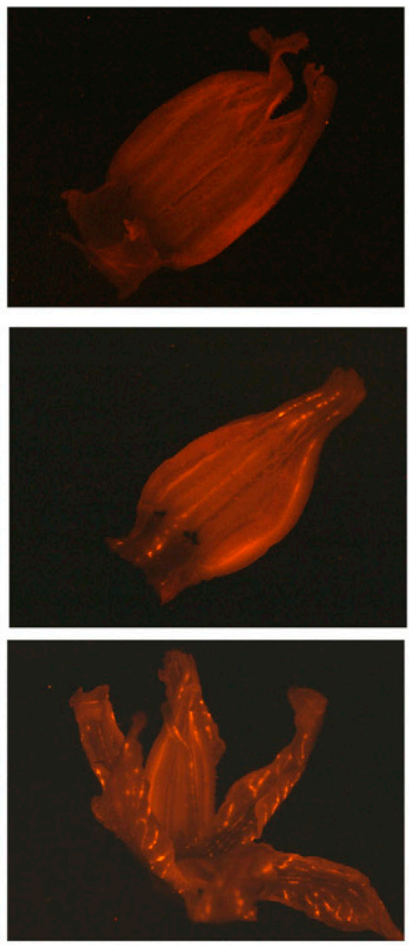

Fig. 4. Tomato yellow leaf curl virus (TYLCV) localization in tomato 2IRDsRed transgenic plants. Flowers from noninfected (mock) plants or from plants systemically infected with an isolate of the Israel strain of TYLCV visualized under an epifluorescence microscope (visible images on the left in each case), with white arrows indicating flower structures. A, Flower $(\mathrm{p}=$ petal and $\mathrm{s}=$ stamen); $\mathbf{B}$, stamen $(\mathrm{s}=$ stamen and $\mathrm{a}=$ anther $)$ and flower without the male reproductive organ showing the pistil $(\mathrm{sg}=$ stigma, $\mathrm{st}=$ style, $\mathrm{o}=$ ovary, and $\mathrm{p}=$ petal $)$; and $\mathbf{C}$, detail of the pistil $(\mathrm{sg}=$ stigma, $\mathrm{st}=$ style, and $\mathrm{o}=\mathrm{ovary})$. Photographs were taken at 11 days postinoculation. 
transgenic lines prepared to monitor TYLCV replication were infected experimentally with the TYLCV-IL isolate ES-Alm-Pep99 and the flowers from systemically infected plants were visualized under an epifluorescence microscope. TYLCV-IL replication could be detected in the petals from both tomato (Fig. 4A) and $N$. benthamiana (Fig. 5A) flowers. Differences were observed, however, when dissected flowers were analyzed. In tomato, DsRed signal was detected in the vascular tissues of the stamens (Fig. 4B) and the style and ovary (Fig. 4B and C). In $N$. benthamiana, TYLCV-IL replication was detected in the ovary septum to which the ovules are attached (Fig. 5B) but no GFP signal was detected in the stamens (Fig. 5C). Moreover, TYLCV-IL replication could be detected in the $N$. benthamiana silique (Fig. 5D). Therefore, the replication and presence of TYLCV-IL in these flower reproductive organs supports the idea that the virus can have access to the seed during maturation.

No evidence of seed transmission of TYLCV-IL to progeny seedlings. The detection of TYLCV-IL in seed of tomato and $N$. benthamiana support its seedborne nature and might suggest the possible seed transmission of the virus to derived seedlings, as observed for other plant viruses (Johansen et al. 1994). Thus, the transmission of TYLCV-IL to progeny plants through seed from TYLCV-IL-infected tomato or $N$. benthamiana plants was investigated. Results of the seed-to-progeny plant transmission assays obtained from more than 3,000 progeny plants evaluated at INIA (location 1) and IHSM-CSIC (location 2) are summarized in Table 4. Progeny plants germinated from tomato seed collected from fruit of plants naturally infected with TYLCV-IL of the five tomato landraces tested did not exhibit symptoms of TYLCVinfection and developed similarly to virus-free control plants 60 days postsowing. Moreover, hybridization and qPCR analysis of seedlings showed no evidence of viral infection regardless of the seed extraction procedure used (Table 4, qPCR results). Negative results in seed transmission were also obtained for progeny plants derived from seed collected from tomato fruit (landraces Marmande and Rondeño and tomato Moneymaker) or N. benthamiana seed capsules of plants experimentally infected with another TYLCV-IL isolate (isolate ES-Alm-Pep-99). In contrast, all positive control plants exhibited prominent TYLCD-infection symptoms from 15 dpi and resulted in clear TYLCV detection (10 positive plants out of 10 plants inoculated experimentally per assay) for tomato Marmande in location 1 and Moneymaker and N. benthamiana in location 2. No TYLCD symptoms were observed and negative detection results were obtained for virus-free control plants. The absence of visible TYLCD-infection symptoms in progeny plants derived from seed collected from fruit of TYLCV-IL-infected tomato plants was also observed by Kil et al. (2016). However, these authors reported a high rate of TYLCV-IL transmission (as much as $80 \%$ virus detection in young tomato plants germinated from seed) from seed-to-progeny plants. These data contrasted with the results obtained here and the findings recently reported by Rajabu et al. (2018) for the fast-growing Florida Lanai tomato variety, which showed no evidence of seed transmission for the four geminiviruses evaluated, including TYLCV-IL. Another recent report has also shown that no seed-to-seedling transmission of TYLCV-IL was observed in $N$. benthamiana, suggesting that seed transmission may not be a general property of TYLCV-IL (Rosas-Díaz et al. 2017).

During the evaluation of seed-to-seedling transmission, one single bulk of 10 tomato plants germinated from seed collected from naturally TYLCV-IL-infected plants of the landrace tomato Melillero revealed a residual signal for TYLCV by qPCR. The 10 plants from the original bulk sample were then analyzed individually by qPCR. Although no robust positive qPCR signal for TYLCV infection was observed in any of the individually analyzed plants, two were used as source plants for a $B$. tabaci transmission assay to 10 virus-free Moneymaker test plants each. In contrast to the results from Kil et al. (2016), which showed TYLCV-IL transmission by whiteflies fed on progeny infected tomato plants, the results obtained here showed that none of the test plants developed TYLCD-infection symptoms even at 60 days after the IAP. Moreover, individual hybridization and bulk qPCR analyses from these test plants also resulted in negative TYLCV detection. In contrast, clear TYLCD symptoms and detection of TYLCV by qPCR was observed in the 10 Moneymaker control test plants in which TYLCV-IL-viruliferous whiteflies were used for transmission. Therefore, the residual qPCR signal detected was more likely related to cross-contamination not associated with a viral infection.

In conclusion, in contrast to the high seed-to-seedling transmission rate reported by Kil et al. (2016) for TYLCV-IL in tomato, no evidence of seed transmission was found for either of the two TYLCV-IL isolates studied here to any of the more than 3,000 progeny plants analyzed from six tomato landraces or Moneymaker. However, TYLCV DNA could consistently be detected in seed collected from fruit (or seed capsules, in the case of $N$. benthamiana) of TYLCV-IL-infected plants. TYLCV-IL could be detected even in internal tissues of seed. Nevertheless, as revised by Johansen et al. (1994), seed transmission of viruses detected on the seed surface or internally may be hampered because, in many cases, the virus is inactivated in both the seed coat and embryo during seed maturation. Conditions prevailing during embryo maturation may not favor virus stability, thus reducing the final seed transmission rate (Bowers and Goodman 1979; Maule and Wang 1996). It is not possible to rule out the existence of TYLCV-IL isolates with different biological features in different tomato varieties that could make them transmissible trough seed. Differences in the ability of virus isolates to invade plant tissues might exist (Cañizares et al. 2015; Johansen et al. 1994; Maule and Wang 1996; Morra and Petty 2000) that can even determine differences in their ability to be seed transmitted (Hampton and Francki 1992;
A

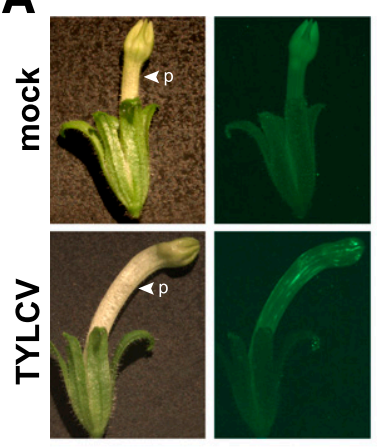

C

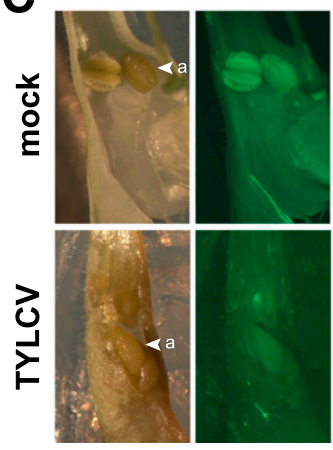

B

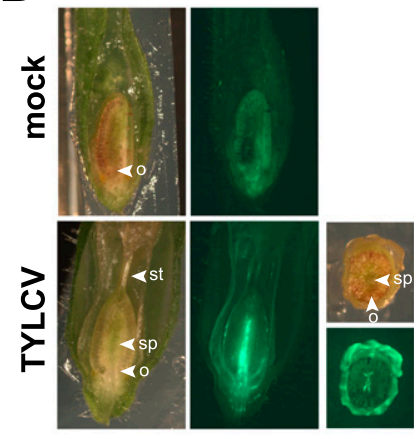

D

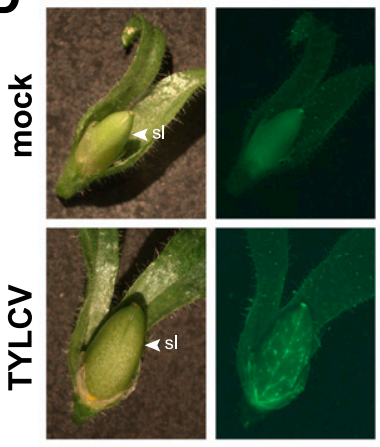

Fig. 5. Tomato yellow leaf curl virus (TYLCV) localization in Nicotiana benthamiana 2IRGFP transgenic plants. Flowers from noninfected (mock) plants or from plants systemically infected with an isolate of the Israel strain of TYLCV visualized under an epifluorescence microscope (visible images on the left [or above in B, transverse section] in each case), with white arrows indicating flower structures. A, Flower ( $\mathrm{p}=$ petal); $\mathbf{B}$, pistil in a longitudinal (left) and a transverse (right) section ( $\mathrm{sp}=$ septum, $\mathrm{st}=$ style, and $\mathrm{o}=$ ovary); $\mathbf{C}$, stamen $(\mathrm{a}=$ anther$)$; and $\mathbf{D}$, silique $(\mathrm{sl}=$ silique) or seed capsule. Photographs were taken at 18 days postinoculation. 


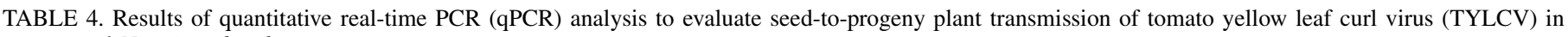
tomato and Nicotiana benthamiana ${ }^{\text {a }}$

\begin{tabular}{|c|c|c|c|c|c|c|c|c|c|c|c|c|}
\hline \multirow[b]{3}{*}{ Landrace or cultivar } & \multicolumn{8}{|c|}{ Location $1^{\mathrm{b}}$} & \multicolumn{4}{|c|}{ Location $2^{\mathrm{b}}$} \\
\hline & \multirow[b]{2}{*}{ Assays $^{c}$} & \multirow[b]{2}{*}{ Plants $^{\mathrm{d}}$} & \multicolumn{2}{|c|}{$\mathrm{W}(n)$} & \multicolumn{2}{|c|}{ WD $(n)$} & \multicolumn{2}{|c|}{$\mathrm{FD}(n)$} & \multirow[b]{2}{*}{ Assays $^{c}$} & \multirow[b]{2}{*}{ Plants $^{\mathrm{d}}$} & \multicolumn{2}{|c|}{$\mathrm{W}(n)$} \\
\hline & & & Bulks e & Pos/total ${ }^{\mathrm{f}}$ & Bulks ${ }^{\mathrm{e}}$ & Pos/total ${ }^{\mathrm{f}}$ & Bulks ${ }^{\mathrm{e}}$ & Pos/total ${ }^{\mathrm{f}}$ & & & Bulks ${ }^{\mathrm{e}}$ & Pos/total ${ }^{\mathrm{f}}$ \\
\hline \multicolumn{13}{|l|}{ Natural infection } \\
\hline Tomato Melillero & $2 / 1 / 1$ & 650 & 25 & $0 / 25$ & 20 & $0 / 20$ & 20 & $0 / 20$ & 3 & 150 & 15 & $0 / 15$ \\
\hline Tomato Rondeño & $2 / 1 / 1$ & 650 & 25 & $0 / 25$ & 20 & $0 / 20$ & 20 & $0 / 20$ & 3 & 150 & 15 & $0 / 15$ \\
\hline Tomato La Carlota & $2 / 0 / 0$ & 250 & 25 & $0 / 25$ & $\ldots$ & $\ldots$ & $\ldots$ & $\ldots$ & 3 & 150 & 15 & $0 / 15$ \\
\hline Tomato Zahara de la Sierra & $2 / 1 / 1$ & 650 & 25 & $0 / 25$ & 20 & $0 / 20$ & 20 & $0 / 20$ & 3 & 150 & 15 & $0 / 15$ \\
\hline Tomato Cherry Canadá & $2 / 0 / 0$ & 250 & 25 & $0 / 25$ & $\ldots$ & $\ldots$ & $\ldots$ & $\ldots$ & 3 & 150 & 15 & $0 / 15$ \\
\hline \multicolumn{13}{|l|}{ Experimental infection ${ }^{g}$} \\
\hline Tomato Marmande & $1 / 0 / 0$ & 50 & 5 & $0 / 5$ & $\ldots$ & $\cdots$ & $\ldots$ & $\ldots$ & $\ldots$ & $\ldots$ & $\ldots$ & $\ldots$ \\
\hline Tomato Rondeño & $1 / 0 / 0$ & 50 & 5 & $0 / 5$ & $\ldots$ & $\ldots$ & $\ldots$ & $\ldots$ & $\ldots$ & $\ldots$ & $\ldots$ & $\ldots$ \\
\hline Tomato Moneymaker & $1 / 0 / 0$ & 50 & 5 & $0 / 5$ & $\ldots$ & $\ldots$ & $\ldots$ & $\ldots$ & $\ldots$ & $\ldots$ & $\ldots$ & $\ldots$ \\
\hline Nicotiana benthamiana & $\ldots$ & $\ldots$ & $\ldots$ & $\ldots$ & $\ldots$ & $\ldots$ & $\ldots$ & $\ldots$ & 1 & 150 & 15 & $0 / 15$ \\
\hline \multicolumn{13}{|l|}{ Virus-free control } \\
\hline Tomato Marmande & $2 / 0 / 0$ & 40 & 4 & $0 / 4$ & $\ldots$ & $\ldots$ & $\ldots$ & $\ldots$ & $\cdots$ & $\cdots$ & $\cdots$ & $\ldots$ \\
\hline Tomato Moneymaker & $\ldots$ & $\cdots$ & $\ldots$ & $\ldots$ & $\ldots$ & $\ldots$ & $\ldots$ & $\ldots$ & 3 & 30 & 3 & $0 / 3$ \\
\hline N. benthamiana & $\ldots$ & $\ldots$ & $\ldots$ & $\ldots$ & $\ldots$ & $\ldots$ & $\ldots$ & $\ldots$ & 1 & 100 & 10 & $0 / 10$ \\
\hline
\end{tabular}

${ }^{a}$ Seed were collected from plants naturally or experimentally infected with isolates of the type (Israel) strain of TYLCV. Progeny plants derived from seed collected from fruit (tomato) or seed capsules (N. benthamiana) of TYLCV-infected or virus-free plants were individually analyzed in location 1 (INIA, Madrid, Spain) and location 2 (IHSM-CSIC, Málaga, Spain) at 60 days after seed sowing for the presence of TYLCV in newly emerged young leaves by tissue-blot hybridization with a probe specific to TYLCV and by qPCR analysis of bulked young leaf samples (10 leaves per bulk). Data are shown for qPCR analysis.

b Seed were collected from tomato fruit by washing with distilled water (W) or $48 \mathrm{~h}$ of fermentation followed by washing with distilled water (F); surface disinfection with $75 \%$ ethanol for $10 \mathrm{~min}$ and $50 \%$ bleach (approximately $1.5 \%$ sodium hypochlorite) for 20 min was done in some seed lots (WD and FD). In $N$. benthamiana, seed were collected from seed capsules and no treatment was given.

${ }^{c}$ Number of independent assays conducted in location 1 with seed from W, WD, and FD extraction procedures (W/WD/FD).

d Total number of analyzed plants.

e Number of analyzed bulks. One bulk $=10$ plants.

f Number of positive bulks/number of total analyzed bulks.

g Plants were experimentally infected by Agrobacterium tumefaciens-mediated inoculation using an infectious clone of the isolate ES-Alm:Pep-99 of the Israel strain of TYLCV.

Hanada and Harrison 1977). In the current study, however, although the seedborne nature of TYLCV-IL was demonstrated, no seed transmission was observed in either tomato or $N$. benthamiana plants for the two different TYLCV-IL isolates evaluated, suggesting that transmission through seed may not be a general strategy in TYLCV spreading. Clarification of this issue is of crucial interest for the seed industry to avoid unjustified phytosanitary barriers in seed trade and to adopt reasonable TYLCV control measures.

\section{ACKNOWLEDGMENTS}

We thank R. Fernández-Muñoz for his help with statistical analyses and figure production.

\section{LITERATURE CITED}

Anabestani, A., Behjatnia, A. S., Izadpanah, K., Tabein, S., and Accotto, P. G. 2017. Seed transmission of Beet curly top virus and Beet curly top Iran virus in a local cultivar of petunia in Iran. Viruses 9:299.

Bowers, G. R., and Goodman, R. M. 1979. Soybean mosaic virus infection of soybean seed parts and seed transmission. Phytopathology 69:569-572.

Brown, J., Zerbini, F. M., Navas-Castillo, J., Moriones, E., Ramos-Sobrinho, R., Silva, J., Fiallo-Olivé, E., Briddon, R., Hernandez-Zepeda, C., Idris, A., Malathi, V. G., Martin, D., Rivera-Bustamante, R., Ueda, S., and Varsani, A. 2015. Revision of Begomovirus taxonomy based on pairwise sequence comparisons. Arch. Virol. 160:1593-1619.

Cañizares, M. C., Rosas-Díaz, T., Rodríguez-Negrete, E., Hogenhout, S. A., Bedford, I. D., Bejarano, E. R., Navas-Castillo, J., and Moriones, E. 2015. Arabidopsis thaliana, an experimental host for tomato yellow leaf curl disease-associated begomoviruses by agroinoculation and whitefly transmission. Plant Pathol. 64:265-271.

Cohen, S., and Antignus, Y. 1994. Tomato yellow leaf curl virus, a whiteflyborne geminivirus of tomatoes. Adv. Dis. Vector Res. 10:259-288.

Córdoba-Sellés, M., García-Randez, A., Alfaro-Fernández, A., and Jorda-Gutierrez, C. 2007. Seed transmission of Pepino mosaic virus and efficacy of tomato seed disinfection treatments. Plant Dis. 91:1250-1254.

De Barro, P. J., Liu, S. S., Boykin, L. M., and Dinsdale, A. B. 2011. Bemisia tabaci: A statement of species status. Annu. Rev. Entomol. 56:1-19.
Edgar, R. C. 2004. MUSCLE: Multiple sequence alignment with high accuracy and high throughput. Nucleic Acids Res. 32:1792-1797.

Fauquet, C., Briddon, R., Brown, J., Moriones, E., Stanley, J., Zerbini, M., and Zhou, X. 2008. Geminivirus strain demarcation and nomenclature. Arch. Virol. 153:783-821.

García-Andrés, S., Accotto, G. P., Navas-Castillo, J., and Moriones, E. 2007. Founder effect, plant host, and recombination shape the emergent population of begomoviruses that cause the tomato yellow leaf curl disease in the Mediterranean basin. Virology 359:302-312.

Gilbertson, R. L., Batuman, O., Webster, C. G., and Adkins, S. 2015. Role of the insect supervectors Bemisia tabaci and Frankliniella occidentalis in the emergence and global spread of plant viruses. Annu. Rev. Virol. 2:67-93.

Haible, D., Kober, S., and Jeske, H. 2006. Rolling circle amplification revolutionizes diagnosis and genomics of geminiviruses. J. Virol. Methods 135:9-16.

Hampton, R. O., and Francki, R. I. B. 1992. RNA-1 dependent seed transmissibility of Cucumber mosaic virus in Phaseolus vulgaris. Phytopathology $82: 127-130$

Hanada, K., and Harrison, B. D. 1977. Effects of virus genotype and temperature on seed transmission of nepo-viruses. Ann. Appl. Biol. 85:79-92.

Hanley-Bowdoin, L., Settlage, S. B., Orozco, B. M., Nagar, S., and Robertson, D. 1999. Geminiviruses: Models for plant DNA replication, transcription, and cell cycle regulation. Crit. Rev. Biochem. Mol. 35:105-140.

Hanssen, I. M., Lapidot, M., and Thomma, B. P. H. J. 2010. Emerging viral diseases of tomato crops. Mol. Plant-Microbe Interact. 23:539-548.

Johansen, E., Edwards, M. C., and Hampton, R. O. 1994. Seed transmission of viruses: Current perspectives. Annu. Rev. Phytopathol. 32:363-386.

Just, K., Arif, U., Luik, A., and Kvarnheden, A. 2017. Monitoring infection of tomato fruit by Tomato yellow leaf curl virus. Plant Pathol. 66:522-528.

Kil, E.-J., Kim, S., Lee, Y. J., Byun, H. S., Park, J., Seo, H., Kim, C. S., Shim, J. K., Lee, J. H., Kim, J. K., Lee, K. Y., Choi, H. S., and Lee, S. 2016. Tomato yellow leaf curl virus (TYLCV-IL): A seed-transmissible geminivirus in tomatoes. Sci. Rep. 6:19013.

Kil, E.-J., Park, J., Choi, E.-Y., Byun, H.-S., Lee, K.-Y., An, C. G., Lee, J.-H., Lee, G.-S., Choi, H.-S., Kim, C.-S., Kim, J.-K., and Lee, S. 2018. Seed transmission of Tomato yellow leaf curl virus in sweet pepper (Capsicum аппиит). Eur. J. Plant Pathol. 150:759-764.

Kil, E.-J., Park, J., Choi, H. S., Kim, C. S., and Lee, S. 2017. Seed transmission of Tomato yellow leaf curl virus in white soybean (Glycine max). Plant Pathol. J. 33:424-428.

Kim, J., Kil, E.-J., Kim, S., Seo, H., Byun, H. S., Park, J., Chung, M. N., Kwak, H. R., Kim, M. K., Kim, C. S., Yang, J. W., Lee, K. Y., Choi, H. S., 
and Lee, S. 2015. Seed transmission of Sweet potato leaf curl virus in sweet potato (Ipomoea batatas). Plant Pathol. 64:1284-1291.

Kothandaraman, S. V., Devadason, A., and Ganesan, M. V. 2016. Seed-borne nature of a begomovirus, Mung bean yellow mosaic virus in black gram. Appl. Microbiol. Biotechnol. 100:1925-1933.

Lefeuvre, P., Martin, D. P., Harkins, G., Lemey, P., Gray, A. J. A., Meredith, S., Lakay, F., Monjane, A., Lett, J. M., Varsani, A., and Heydarnejad, J. 2010. The spread of tomato yellow leaf curl virus from the Middle East to the world. PLoS Pathog. 6:e1001164.

Lozano-Durán, R., Rosas-Díaz, T., Luna, A. P., and Bejarano, E. R. 2011. Identification of host genes involved in geminivirus infection using a reverse genetics approach. PLoS One 6:e22383.

Luna, A. P., Morilla, G., Voinnet, O., and Bejarano, E. R. 2012. Functional analysis of gene-silencing suppressors from tomato yellow leaf curl disease viruses. Mol. Plant-Microbe Interact. 25:1294-1306.

Maio, F., Arroyo-Mateos, M., Bobay, B. G., Bejarano, E. R., Prins, M., and van den Burg, H. A. 2019. A lysine residue essential for geminivirus replication also controls nuclear localization of the Tomato yellow leaf curl virus Rep protein. J. Virol. 93:e01910-18.

Manivannan, K., Renukadevi, P., Malathi, V. G., Karthikeyan, G., and Balakrishnan, N. 2019. A new seed-transmissible begomovirus in bitter gourd (Momordica charantia L.). Microb. Pathog. 128:82-89.

Mason, G., Caciagli, P., Accotto, G. P., and Noris, E. 2008. Real-time PCR for the quantitation of Tomato yellow leaf curl Sardinia virus in tomato plants and in Bemisia tabaci. J. Virol. Methods 147:282-289.

Maule, A. J., and Wang, D. 1996. Seed transmission of plant viruses: A lesson in biological complexity. Trends Microbiol. 4:153-158.

Monci, F., García-Andrés, S., Maldonado, J. A., and Moriones, E. 2005. Resistance to monopartite begomoviruses associated with the bean leaf crumple disease in Phaseolus vulgaris controlled by a single dominant gene. Phytopathology 95:819-826.

Monci, F., Sánchez-Campos, S., Navas-Castillo, J., and Moriones, E. 2002. A natural recombinant between the geminiviruses Tomato yellow leaf curl Sardinia virus and Tomato yellow leaf curl virus exhibits a novel pathogenic phenotype and is becoming prevalent in Spanish populations. Virology 303: 317-326.

Morilla, G., Castillo, A. G., Preiss, W., Jeske, H., and Bejarano, E. R. 2006. A versatile transreplication-based system to identify cellular proteins involved in geminivirus replication. J. Virol. 80:3624-3633.

Morilla, G., Janssen, D., García-Andrés, S., Moriones, E., Cuadrado, I. M., and Bejarano, E. R. 2005. Pepper (Capsicum annuum) is a dead-end host for Tomato yellow leaf curl virus. Phytopathology 95:1089-1097.

Moriones, E., and Navas-Castillo, J. 2000. Tomato yellow leaf curl virus, an emerging virus complex causing epidemics worldwide. Virus Res. 71: 123-134.

Moriones, E., Navas-Castillo, J., and Díaz-Pendon, J. A. 2011. Emergence of begomovirus diseases. Pages 301-320 in: Recent Advances in Plant Virology. C. Caranta, M. A. Aranda, M. Tepfer, and J. J. Lopez-Moya, eds. Caister Academic Press, Norfolk, VA, U.S.A.

Morra, M. R., and Petty, I. T. D. 2000. Tissue specificity of geminivirus infection is genetically determined. Plant Cell 12:2259-2270.

Muhire, B. M., Varsani, A., and Martin, D. P. 2014. SDT: A virus classification tool based on pairwise sequence alignment and identity calculation. PLoS One 9:e108277.

Navas-Castillo, J., Fiallo-Olivé, E., and Sánchez-Campos, S. 2011. Emerging virus diseases transmitted by whiteflies. Annu. Rev. Phytopathol. 49: 219-248.

Navas-Castillo, J., Sánchez-Campos, S., Díaz, J. A., Sáez-Alonso, E., and Moriones, E. 1999. Tomato yellow leaf curl virus-Is causes a novel disease of common bean and severe epidemics in tomato in Spain. Plant Dis. 83: 29-32.

Nemati, H., Nazdar, T., Azizi, M., and Arouiee, H. 2010. The effect of seed extraction methods on seed quality of two cultivar's tomato (Solanum lycopersicum L.). Pak. J. Biol. Sci. 13:814-820.

Péréfarres, F., Thierry, M., Becker, N., Lefeuvre, P., Reynaud, B., Delatte, H., and Lett, J.-M. 2012. Biological invasions of geminiviruses: Case study of TYLCV and Bemisia tabaci in Reunion Island. Viruses 4:3665-3688.

Permingeat, H. R., Romagnoli, M. V., Sesma, J. I., and Vallejos, R. H. 1998. A simple method for isolating DNA of high yield and quality from cotton (shape Gossypium hirsutum L.) leaves. Plant Mol. Biol. Rep. 16:89-89.

Rajabu, C. A., Kennedy, G. G., Ndunguru, J., Ateka, E. M., Tairo, F., Hanley-Bowdoin, L., and Ascencio-Ibáñez, J. T. 2018. Lanai: A small, fast growing tomato variety is an excellent model system for studying geminiviruses. J. Virol. Methods 256:89-99.

Rodríguez-Negrete, E., Lozano-Durán, R., Piedra-Aguilera, A., Cruzado, L., Bejarano, E. R., and Castillo, A. G. 2013. Geminivirus Rep protein interferes with the plant DNA methylation machinery and suppresses transcriptional gene silencing. New Phytol. 199:464-475.

Rojas, M. R., Macedo, M. A., Maliano, M. R., Soto-Aguilar, M., Souza, J. O., Briddon, R. W., Kenyon, L., Bustamante, R. F. R., Zerbini, F. M., Adkins, S., Legg, J. P., Kvarnheden, A., Wintermantel, W. M., Sudarshana, M. R., Peterschmitt, M., Lapidot, M., Martin, D. P., Moriones, E., Inoue-Nagata, A. K., and Gilbertson, R. L. 2018. World management of geminiviruses. Annu. Rev. Phytopathol. 56:637-677.

Rosas-Díaz, T., Zhang, D., and Lozano-Durán, R. 2017. No evidence of seed transmissibility of Tomato yellow leaf curl virus in Nicotiana benthamiana. J. Zhejiang Univ. Sci. B 18:437-440.

Rosen, R., Kanakala, S., Kliot, A., Cathrin Pakkianathan, B., Farich, B. A., Santana-Magal, N., Elimelech, M., Kontsedalov, S., Lebedev, G., Cilia, M., and Ghanim, M. 2015. Persistent, circulative transmission of begomoviruses by whitefly vectors. Curr. Opin. Virol. 15:1-8.

Rybicki, E. 2015. A top ten list for economically important plant viruses. Arch. Virol. 160:17-20.

Sánchez-Campos, S., Díaz, J. A., Monci, F., Bejarano, E. R., Reina, J., Navas-Castillo, J., Aranda, M. A., and Moriones, E. 2002. High genetic stability of the begomovirus Tomato yellow leaf curl Sardinia virus in southern Spain over an 8-year period. Phytopathology 92:842-849.

Sánchez-Campos, S., Navas-Castillo, J., Camero, R., Soria, C., Díaz, J. A., and Moriones, E. 1999. Displacement of tomato yellow leaf curl virus (TYLCV)-Sr by TYLCV-Is in tomato epidemics in Spain. Phytopathology 89:1038-1043.

Sangeetha, B., Malathi, V. G., Alice, D., Suganthy, M., and Renukadevi, P. 2018. A distinct seed-transmissible strain of Tomato leaf curl New Delhi virus infecting chayote in India. Virus Res. 258:81-91.

Suruthi, V., Nakkeeran, S., Renukadevi, P., Malathi, V. G., and Rajasree, V. 2018. Evidence of seed transmission of Dolichos yellow mosaic virus, a begomovirus infecting lablab-bean in India. VirusDisease 29:506-512.

Wang, B., Li, F., Huang, C., Yang, X., Qian, Y., Xie, Y., and Zhou, X. 2014. V2 of Tomato yellow leaf curl virus can suppress methylation-mediated transcriptional gene silencing in plants. J. Gen. Virol. 95:225-230.

Weller, S. A., Elphinstone, J. G., Smith, N. C., Boonham, N., and Stead, D. E. 2000. Detection of Ralstonia solanacearum strains with a quantitative, multiplex, real-time, fluorogenic PCR (TaqMan) assay. Appl. Environ. Microbiol. 66:2853-2858.

Zerbini, F., Briddon, R. W., Idris, A., Martin, D. P., Moriones, E., Navas-Castillo, J., Rivera-Bustamante, R., Roumagnac, P., and Varsani, A. 2017. ICTV virus taxonomy profile. Geminiviridae. J. Gen. Virol. 98: $131-133$. 